\title{
Annual Report on the External Quality Assessment Scheme of Viral Markers and Serological Tests for Syphilis in Korea (2015)
}

Young Joo Cha ${ }^{1}$, Jae Hoon Bae ${ }^{1}$, Young Soon Jung ${ }^{1}$, and Seok Lae Chae ${ }^{2}$, as the Immunoserology Subcommittee, Korean Association of External Quality Assessment Service

${ }^{1}$ Department of Laboratory

Medicine, Chung-

Ang University College

of Medicine, Seoul;

${ }^{2}$ Department of Laboratory

Medicine, Dongguk

University Ilsan Hospital, Dongkuk University College of Medicine, Goyang, Korea

Corresponding author:

Young Joo Cha

Department of Laboratory

Medicine, Chung-Ang University

College of Medicine, 84 Heukseok-

ro, Dongjak-gu, Seoul 06974,

Korea

Tel: $+82-2-6299-2720$

Fax: +82-2-6298-8630

E-mail: chayoung@cau.ac.kr

pISSN: 2384-2458

elSSN: 2288-7261
As the Immunoserology Subcommittee of the Korean Association of External Quality Assessment, we organized two trials on the external quality assessment of viral markers and serological tests for syphilis (STS) in 2015. For this purpose, we delivered three kinds of pooled sera specimens for external proficiency testing to 1,071 and 1,074 institutions for the first and second trials, respectively. Pooled sera were checked for their homogeneity and stability using multiple methods between the day of their manufacture and three days after dispatching. The number of participating laboratories was 1,055 (98.5\%) and 1,055 (98.2\%) in the first and second trial, respectively. The most commonly tested items were hepatitis B surface antigen, followed by the antibodies to hepatitis B surface antigen, antihuman immunodeficiency virus, anti-hepatitis C virus, STS, and anti-hepatitis B core. The most frequently used methods for detecting viral markers were the chemiluminescence immunoassay (CLIA) and the electrochemiluminescence immunoassay, which were found to generate few false positive results. In contrast, false negative results were frequently found when the immunochromatographic assay (ICA) was used; the use of ICA for detecting viral markers has been steadily increasing in recent years. Furthermore, the use of turbidoimmunoassay and CLIA, tests recently introduced for the measurement of nontreponemal and treponemal antibodies, is also increasing.

(J Lab Med Qual Assur 2016;38:214-224)

Key Words: External quality assessment, Hepatitis B, Hepatitis C, HIV, Immunoassay, Laboratory proficiency testing, Serology, Syphilis

\section{서론}

대한임상검사정도관리협회 면역혈청분과위원회는 1982 년 B형간염표면항원(hepatitis B surface antigen, HBsAg) 과 매독혈청검사(serologic test for syphilis, STS)에 대한 신 빙도조사를 시작으로[1], 1983년부터 항-스트렙토라이신 O (anti-streptolysin O, ASO)와 위달(Widal) [2], 1986년부 터 C-반응단백(C-reactive protein, $\mathrm{CRP}$ ), 류마토이드인자 (rheumatoid factor, $\mathrm{RF}$ ), 및 $\mathrm{B}$ 형간염표면항체(antibody to hepatitis B surface antigen, anti-HBs) [3], 1992년부터 에 이즈항체(anti-human immunodeficiency virus, anti-HIV), 1993년부터 C형간염항체(anti-hepatitis C virus, anti-HCV) 


\section{Journal of LABORATORY MEDICINE and QUALITY ASSURANCE}

Young Joo Cha et al • EQA Report for Immunoserology (2015)

[4], 2004년부터 B형간염중심항체(antibody to hepatitis B core antigen, anti- $\mathrm{HBc}$ )가[5] 각각 추가되어 현재 $\mathrm{HBsAg}$, anti-HBs, anti-HBc, anti-HCV, anti-HIV, STS, ASO, Widal, $\mathrm{CRP}, \mathrm{RF}$ 등 총 10 종목에 대하여 연 2회 신빙도조사 를 실시하고 있다. 저자들은 2013년부터 이 중 HBsAg, anti$\mathrm{HBs}$, anti-HBc, anti-HCV, anti-HIV 등의 바이러스 항원/ 항체 및 STS검사의 신빙도조사결과를 별도로 분석하여 보고 하고 있는 바[6,7], 2015년에 실시한 바이러스 항원/항체 및 STS검사의 신빙도조사결과를 분석하여 전년도와 비교 분석하 고자 한다.

\section{재료 및 방법}

\section{1. 신빙도조사 검체 및 대상기관}

총 2회에 걸쳐 바이러스 항원/항체 및 STS에 대한 신빙도조 사를 실시하였다. 1회차 신빙도조사 검체는 바이러스 항원/항 체검사용 2개(15-S-3, 15-S-4)와 STS용 1개(15-S-5)로 총 3 개의 검체를 1,071 개 기관에, 2 회차에도 1 회차와 마찬가지로 총 3개의 검체 $(15-\mathrm{S}-8,15-\mathrm{S}-9,15-\mathrm{S}-10)$ 를 1,074 개 기관에 각각 2015년 5월과 11월에 발송하였다.

\section{2. 신빙도조사 대상종목}

신빙도조사 대상종목은 $\mathrm{HBsAg}$, anti-HBs, anti-HBc, anti-HCV, anti-HIV, 및 STS로 총 6종목이었고, 1회와 2회 차 모두 동일한 종목을 대상으로 하였다.

\section{3. 신빙도조사 검체 제조방법}

신빙도조사를 위한 검체는 '인체유래 고위험군바이러스 소 재은행'인 ‘중앙대학교병원 혈청검체은행’으로부터 혈청을 분 양받아 각 종목의 양성과 음성 신빙도조사 검체를 제조하였다. 냉동 보관된 혈청을 실온에서 해동한 후 $56^{\circ} \mathrm{C}$ 에서 3 시간 불활 성화시키고 $0.22 \mu \mathrm{m}$ 필터에서 1 회 여과시켰다. 적절한 역가가 되도록 양성 및 음성 혈청을 혼합하고 7일간 냉장고에 보관하 면서 1시간 간격으로 교반기에서 $150 \mathrm{rpm}$ 으로 혼합하여 균질 한 검체를 제조하였다. 이후 검체 균질성(homogeneity) 및 안 정성(stability) 검사를 실시하였고, 검체를 담을 작은 병(vial) 과 고무마개를 ethylene oxide 가스로 멸균하고, 무균실험대 (clean bench)에서 작은 병에 $1 \mathrm{~mL}$ 씩 분주한 후 고무마개를 밀봉(packing)하였다. 용기의 파손을 대비하여 추가로 스크류 캡(skew cap)에 밀봉하여 발송하였다.

\section{4. 신빙도조사 검체의 균질성 및 안정성 평가}

신빙도조사 검체의 균질성은 조제 후 발송 전에 실시하였 는데, 병내 균질성(intra-vial homogeneity)은 냉장 보관하 면서 한 세트로 5 회 반복 측정하였고, 병간 균질성(inter-vial homogeneity)은 냉장 보관하면서 5세트로 1 회 측정하였다. 안정성(stability)은 냉장 보관하면서 제조당일, 발송 1-3주 전, 발송 당일 및 발송 후 3 일로 분류한 뒤 각 검사종목을 측정 하여 목표한 결과치가 유지되는지 검토하였다. 균질성 및 안정 성 검토에 사용된 시약 및 검사방법은 3종류 이상의 서로 다른 시약과 장비로 확인하였다(Table 1).

\section{5. 결과분석 및 통계}

결과는 인터넷 및 우편을 이용하여 접수하였고, 결과분석 은 각 검사종목별로 검사방법별(peer group) 결과와 전체 (total) 결과로 정리하였다. 통계처리는 Microsoft Excel 2010 (Microsoft, Redmond, WA, USA) 프로그램을 사용하였다.

\section{결과}

\section{1. 참여기관 및 회신율}

최소 1 종목 이상 신빙도조사에 참여한 기관들을 기준으로, 1 회차는 1,071 기관 중 1,055 기관이, 2 회차는 1,074 기관 중 1,055 기관이 회신하여 회신율은 각각 $98.5 \%, 98.2 \%$ 였다. 2 차 신빙도조사를 기준으로 각 기관 유형별 참여현황 및 세부 종목별 참여현황은 Table 2에 정리하였다. 결과는 인터넷 및 우편으로 접수하였는데, 1 차, 2 차 조사에서 회신한 모든 기관 $(100 \%)$ 이 인터넷으로 회신하였다.

\section{2. 신빙도조사 검체의 균질성 및 안정성 결과}

신빙도조사 검체의 병내 및 병간 균질성은 모두 균질하게 제 조되었음을 확인할 수 있었고(양성 및 음성 결과 동일), 냉장 안정성 역시 제조 후 잘 유지되고 있음을 확인하였다(Fig. 1).

\section{3. 검사방법 및 검사장비}

신빙도조사에 참여한 기관들의 검사종목별 검사방법 및 사 용장비는 결과보고지에 각 기관이 기재한 코드를 바탕으로 분 석하였다. 시약코드와 검사방법코드 또는 사용장비코드가 일 치하지 않는 경우 시약코드를 중심으로 분류하였고, 경우에 따 라서는 참여기관에 문의하여 확인한 후 수정하였다.

1) 바이러스 항원 및 항체검사의 검사방법과 검사장비

2차 신빙도조사를 기준으로 각 검사실에서 사용한 검사방 


\section{Journal of LABORATORY MEDICINE and QUALITY ASSURANCE}

\section{Young Joo Cha et al • EQA Report for Immunoserology (2015)}

Table 1. Methods used for checking homogeneity and stability of control specimens

\begin{tabular}{llll}
\hline \multicolumn{1}{c}{ Test item } & Method & \multicolumn{1}{c}{ Instruments } & \multicolumn{1}{c}{ Reagents } \\
\hline Viral antigen or antibody & ECLIA & E170, Roche & Reagent for E170 \\
& CLIA & Architect, Abbott & Reagent for Architect \\
& & Centaur XP, Siemens & Reagent for Centaur XP \\
ICA & Manual & SD/Green Cross MS/Asan device kit \\
Non-treponemal test & TIA & AU5400, Beckman & Mediace RPR \\
VDRL & Manual & BD VDRL Antigen for syphilis serology \\
RPR & Manual & Asan RPR card test \\
& & IVD Labslide RPR \\
& TIA & BD Macro-Vue RPR card test \\
TPPA & AU5400, Beckman & Mediace TPLA \\
& ICA & Manual & SERODIA-TPPA \\
& Manual & SD Syphilis 3.0 kit \\
& & Asan Easy Test Syphilis \\
& & Humasis Syphilis card
\end{tabular}

The following test was used: E170 (Roche Diagnostics GmbH, Mannheim, Germany), Architect (Abbott Diagnostics, Abbott Park, IL, USA), Centaur XP (Siemens Healthcare Diagnostics, Tarrytown, NY, USA), and AU5400 (Beckman Coulter Inc., Brea, CA, USA).

Abbreviations: ECLIA, electrochemiluminescence immunoassay; CLIA, chemiluminescence immunoassay, ICA, immunochromatography assay; TIA, turbidoimmunoassay; VDRL, Venereal Disease Research Laboratory; RPR, rapid plasma regain; TPPA, Treponema pallidum particle agglutination.

Table 2. Response rate of the second trial of 2015 on syphilis proficiency using viral markers and serological tests

\begin{tabular}{lrrrrrrrr}
\hline \multirow{2}{*}{ Type of institution } & Subtotal & \multicolumn{7}{c}{ Test items } \\
\cline { 3 - 8 } & & HBsAg & Anti-HBs & Anti-HBc & Anti-HCV & Anti-HIV & Non-T & T \\
\hline General hospital & 260 & 259 & 258 & 50 & 250 & 258 & 243 & 102 \\
University hospital & 76 & 76 & 76 & 58 & 75 & 75 & 73 & 59 \\
Small hospital \& physician's clinic & 585 & 578 & 575 & 13 & 395 & 355 & 288 & 92 \\
Military hospital & 47 & 47 & 38 & 2 & 42 & 46 & 14 & 20 \\
Public laboratory & 43 & 43 & 43 & 0 & 20 & 39 & 36 \\
Health-promotion organisation & 12 & 10 & 10 & 0 & 3 & 7 & 6 \\
Independent medical laboratory & 21 & 21 & 21 & 10 & 19 & 20 & 17 \\
Blood-laboratory centre & 4 & 4 & 0 & 0 & 4 & 4 & 3 \\
Research institute & 7 & 7 & 5 & 2 & 6 & 6 & 4 \\
Total no. & 1,055 & 1,045 & 1,021 & 135 & 814 & 805 & 684 \\
Response rate (\%) & - & 99.1 & 96.8 & 12.8 & 77.2 & 6.3 & 64.8 \\
\hline
\end{tabular}

Abbreviations: HBsAg, hepatitis B surface antigen; Anti-HBs, antibody to HBsAg; Anti-HBc, antibody to hepatitis B core antigen; Anti-HCV, antibody to hepatitis $\mathrm{C}$ virus; Anti-HIV, antibody to human immunodeficiency virus; $\mathrm{T}$, treponemal tests.

법을 정리해보면, $\mathrm{HBsAg}$ 및 anti-HBs검사는 각각 $73.0 \%$, $72.4 \%$ 의 기관이, anti-HBc검사는 전 기관에서, anti-HCV 및 anti-HIV검사는 각각 $67.3 \%$ 와 $72.4 \%$ 의 기관이 효소 면역검사법(enzyme immunoassay, EIA), 미세입자효 소면역검사법(microparticle EIA), 화학발광면역검사법 (chemiluminescence immunoassay, CLIA), 전기화학발 


\section{A}

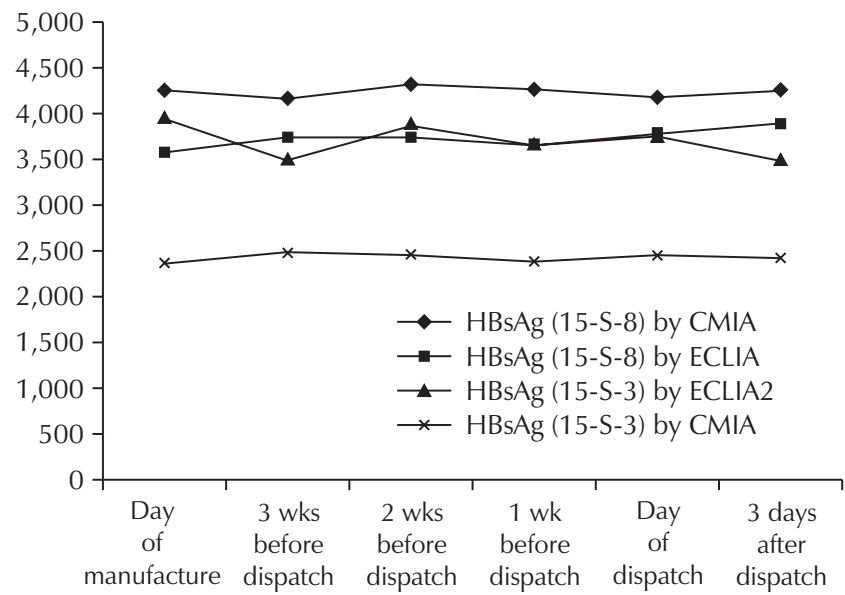

C

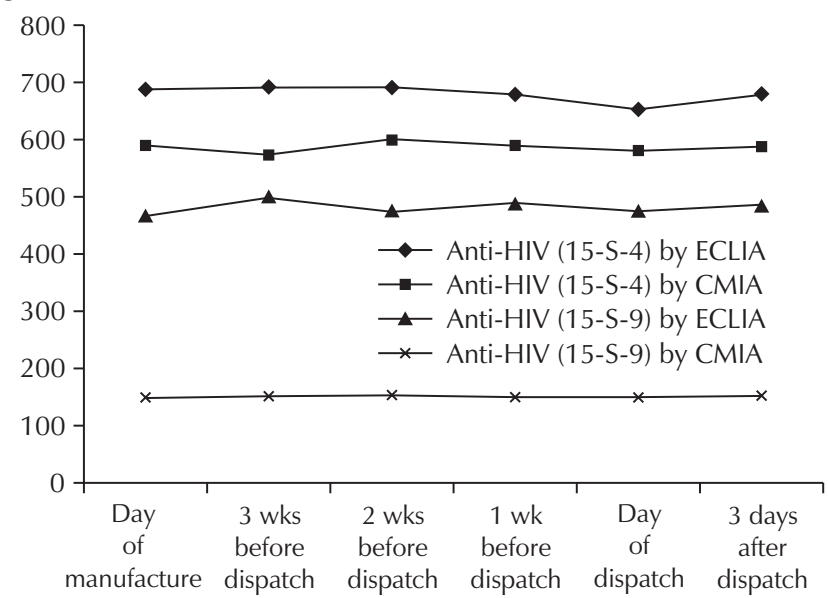

B

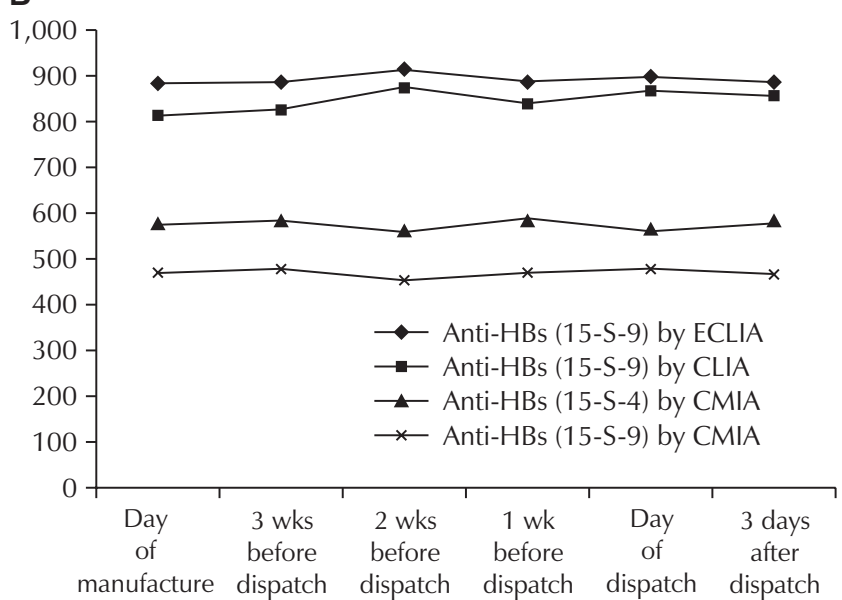

D

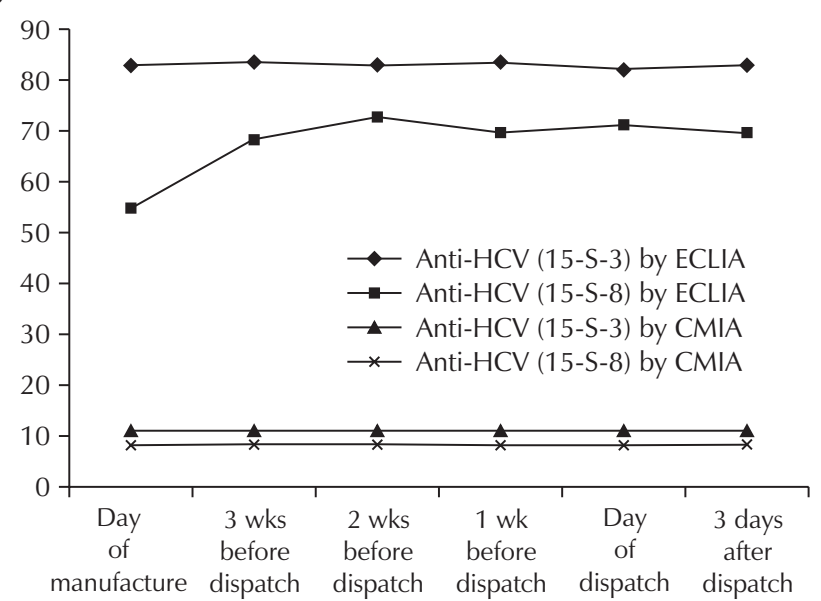

Fig. 1. Stability results of proficiency test samples for (A) HBsAg, (B) anti-HBs, (C) anti-HIV, and (D) anti-HCV. The X-axis shows the time-points tested and the Y-axis shows the results obtained. The units of the Y-axis are the signal to cut-off ratio in HBsAg, anti-HCV, and anti-HIV and IU/L in anti-HBs. The cut-off ratio to differentiate between positive and negative results is 1 for HBsAg, anti-HCV, and anti-HIV and 10 IU/L for anti-HBs. Abbreviations: HBsAg, hepatitis B surface antigen; anti-HBs, antibody to hepatitis B surface antigen; anti-HIV, anti-human immunodeficiency virus; anti-HCV, anti-hepatitis C virus; ECLIA, electrochemiluminescence immunoassay; CMIA, carbonylmetalloimmunoassay.

광면역검사법(electrochemiluminescence immunoassay, ECLIA) 및 형광효소면역검사법(fluorescence enzyme immunoassay) 등 민감도가 우수한 자동화 검사법으로 검 사를 실시하고 있었다. 정성분석법인 면역크로마토그래피법 (immunochromatographic assay, ICA)은 HBsAg 및 anti$\mathrm{HBs}$ 검사에서는 각각 $28.2 \%, 27.6 \%$ 의 기관에서, anti-HCV 검사에서는 $33.7 \%$ 의 기관에서, anti-HIV검사에서는 $27.6 \%$ 의 기관에서 사용되고 있었다(Table 3). 검사장비별로 분류해 보면 CLIA장비로는 Abbott사(Abbott Diagnostics, Abbott Park, IL, USA)의 Architect, Roche사(Roche Diagnostics
$\mathrm{GmbH}$, Mannheim, Germany)의 Elecsys 2010과 E170, Siemens사(Siemens Healthcare Diagnostics, Tarrytown, $\mathrm{NY}$, USA)의 Advia Centaur 등이 많이 사용되고 있었고, EIA장비로는 BioMérieux사(BioMérieux, Marcy l’Etoile, France)의 VIDAS, Abbott사(Abbott Diagnostics)의 Asxym 장비 등이 많이 사용되고 있었다(Table 4).

2) 매독혈청검사 검사방법

비트레포네마(non-treponemal, non-T)검사는 rapid plasma reagin (RPR)법이 1, 2차 신빙도조사에서 각각 


\section{Journal of LABORATORY MEDICINE and QUALITY ASSURANCE}

\section{Young Joo Cha et al • EQA Report for Immunoserology (2015)}

Table 3. Principles of methods used measuring viral antigens or antibodies in the second trial of the 2015 proficiency testing

\begin{tabular}{|c|c|c|c|c|c|}
\hline Method & HBsAg & Anti-HBs & Anti-HBc & Anti-HCV & Anti-HIV \\
\hline EIA & $5(0.5)$ & $5(0.5)$ & - & $14(1.7)$ & $17(2.1)$ \\
\hline MEIA & - & - & $1(0.7)$ & - & - \\
\hline CLIA & $411(39.3)$ & $406(39.8)$ & $90(66.7)$ & $344(42.2)$ & $344(42.7)$ \\
\hline ECLIA & $315(30.1)$ & $297(29.1)$ & 39 (28.9) & $182(22.4)$ & $204(25.3)$ \\
\hline FEIA & $32(3.1)$ & $31(3.0)$ & $5(3.7)$ & - & $18(2.2)$ \\
\hline ICA & $282(27.0)$ & $282(27.6)$ & - & $274(33.7)$ & $222(27.6)$ \\
\hline RPHA/PHA/PA & - & - & - & - & - \\
\hline Total & $1,045(100.0)$ & $2,021(100.0)$ & $134(100.0)$ & $814(100.0)$ & $805(100.0)$ \\
\hline
\end{tabular}

Values are presented as number (\%).

Abbreviations: $\mathrm{HBsAg}$, hepatitis B surface antigen; Anti-HBs, antibody to HBsAg; Anti-HBc, antibody to hepatitis B core antigen; Anti$\mathrm{HCV}$, antibody to hepatitis $\mathrm{C}$ virus; Anti-HIV, antibody to human immunodeficiency virus; EIA, enzyme immunoassay; MEIA, microparticle EIA; CLIA, chemiluminescence immunoassay; ECLIA, electrochemiluminescence immunoassay; FEIA, fluorescent EIA; ICA, immunochromatography assay; RPHA, reversed passive haemagglutination; PHA, passive haemagglutination; PA, particle agglutination.

Table 4. Instruments used to measure viral antigens or antibodies in the second trial of the 2015 proficiency testing

\begin{tabular}{|c|c|c|c|c|c|c|c|}
\hline Manufacturer & Instrument & Method & HBsAg & Anti-HBs & Anti-HBc & Anti-HCV & Anti-HIV \\
\hline \multirow[t]{2}{*}{ Abbott } & Architect & CLIA & 231 & 230 & 75 & 226 & 222 \\
\hline & IMx & MEIA & - & - & 1 & - & - \\
\hline Siemens & Centaur & CLIA & 101 & 101 & 15 & 75 & 72 \\
\hline Beckman & Access & CLIA & 33 & 33 & - & 20 & 29 \\
\hline Siemens & BEP series & EIA & - & - & - & 1 & 1 \\
\hline BioMéerieux & VIDAS & Fluorescent EIA & 30 & 29 & 5 & - & 18 \\
\hline Bio-Rad & Coda & EIA & - & - & - & - & 1 \\
\hline DPC & Immulite & CLIA & 6 & 6 & - & - & - \\
\hline Ortho & Vitros Eci & CLIA & 16 & 16 & - & 15 & 15 \\
\hline \multirow[t]{3}{*}{ Roche } & Elecsys 2010 & ECLIA & 174 & 171 & 2 & 99 & 96 \\
\hline & $\mathrm{E} 170$ & ECLIA & 133 & 119 & 37 & 82 & 96 \\
\hline & Cobas series & ECLIA & 8 & 7 & & 1 & 5 \\
\hline SEAC & Alisei & EIA & 4 & 4 & - & 7 & 7 \\
\hline Others & & & 33 & 23 & - & 14 & 17 \\
\hline Total & & & 769 & 739 & 135 & 540 & 586 \\
\hline
\end{tabular}

The following test was used: Architect, IMx (Abbott Diagnostics, Abbott Park, IL, USA), Centaur, BEP series (Siemens Healthcare Diagnostics, Tarrytown, NY, USA), Access (Beckman Coulter Inc., Brea, CA, USA), VIDAS (BioMérieux, Marcy l'Etoile, France), Coda (Bio-Rad Laboratories, Hercules, CA, USA), Immulite (DPC, Los Angeles, CA, USA), Vitros Eci (Ortho Clinical Diagnostics, Raritan, NJ, USA), Elecsys2010, E170, Cobas series (Roche Diagnostics GmbH, Mannheim, Germany), and Alisei (SEAC, Pomezia, Italy).

Abbreviations: HBsAg, hepatitis B surface antigen; Anti-HBs, antibody to HBsAg; Anti-HBc, antibody to hepatitis B core antigen; Anti$\mathrm{HCV}$, antibody to hepatitis C virus; Anti-HIV, antibody to human immnodeficiency virus; CLIA, chemiluminescence immunoassay; MEIA, microparticle enzyme immunoassay; EIA, enzyme immunoassay; ECLIA, eletro-chemiluminescence immunoassay.

$65.8 \%, 65.9 \%$ 로 대부분의 기관에서 $\mathrm{RPR}$ 법을 사용하고 있 었고, 정량검사법인 혼탁면역측정법(turbidoimmunoassay, TIA)으로 보고한 기관은 $32.0 \%, 32.3 \%$ 였다(Table 5 ). Venereal Disease Research Laboratory법을 사용한 기
관은 각각 $2.2 \%, 1.8 \%$ 였다. 트레포네마(treponemal, T) 검사에서는 ICA법 $(43.4 \%, 43.9 \%)$ 과 입자응집법(particle agglutination, PA; $33.2 \%, 33.3 \%)$ 이 주로 이용되고 있었 고, TIA법은 $11.1 \%, 11.3 \%$ 의 기관에서 사용하고 있으며, 형 


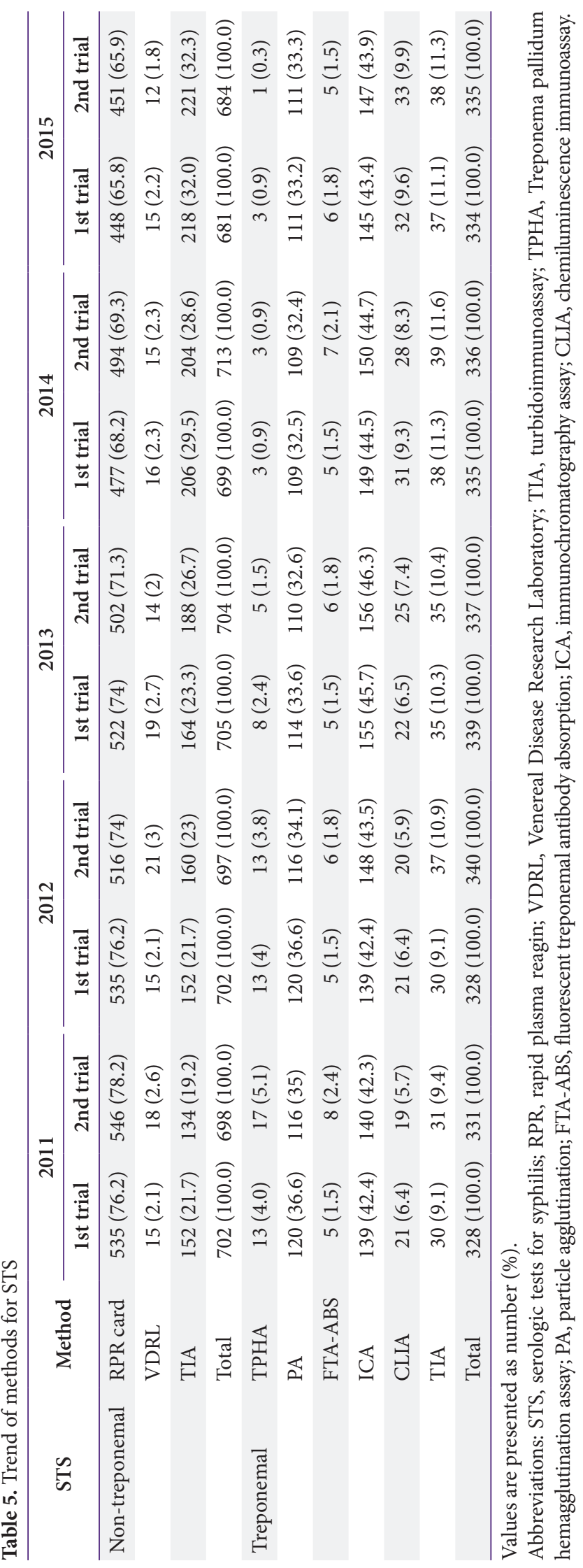

광트레포네마항체흡수법(fluorescent treponemal antibody absorption) 등은 소수의 기관(1.8\%, 1.5\%)에서만 실시되고 있었다. 최근 5년간(2011-2015년) STS 검사방법의 변화 추 이를 보면 non-T검사에서는 RPR card 검사법이 지속적으로 감소하고 있는 반면 TIA법이 증가하고 있으며, T검사에서는 CLIA법과 TIA법이 아직은 사용하는 기관이 적지만 서서히 증가하고 있다(Fig. 2).

\section{4. 종목별 결과분석}

\section{1) $B$ 형간염표면항원}

$\mathrm{HBsAg}$ 검사에 대한 신빙도조사 결과, 1 차의 $15-\mathrm{S}-3$ 검체 와 2차의 15-S-8 검체는 양성 검체로 각각 1,047 기관 중 1,046 기관, 1,045 기관 중 1,045 기관에서 양성으로 보고하여 각각 $99.9 \%$ 와 $100.0 \%$ 의 높은 일치율을 보였다(Table 6$)$. 한편 1 차의 $15-\mathrm{S}-4$ 검체와 2 차의 $15-\mathrm{S}-9$ 검체는 음성 검체로 각각 1,047 기관 중 1,041 기관, 1,045 기관 중 1,039 기관에서 음성으 로 보고하여 모두 $99.4 \%$ 의 일치율을 보였다(Table 6).

\section{2) B형간염표면항체}

Anti-HBs검사에 대한 신빙도조사 결과, 1 차의 $15-\mathrm{S}-3$ 검체 와 2차의 15-S-8 검체는 음성 검체로 각각 1,022 기관 중 1,017 기관, 1,021 기관 중 1,013 기관이 음성으로 보고하여 각각 $99.5 \%, 99.2 \%$ 의 높은 일치율을 보였다(Table 7). 또한 1차의 $15-\mathrm{S}-4$ 검체와 $15-\mathrm{S}-9$ 검체는 양성 검체로 1 차의 1,022 기관과 2 차의 1,021 기관 중 전 기관에서 양성으로 보고하여 $100.0 \%$ 의 높은 일치율을 보였다(Table 7).

\section{3) $B$ 형간염중심항체}

$\mathrm{Anti}-\mathrm{HBc}$ 검사에 대한 신빙도조사 결과, 1 차의 $15-\mathrm{S}-3,15-$ S-4 검체와 2차의 $15-\mathrm{S}-8,15-\mathrm{S}-9$ 검체 모두 양성 검체였는 데, 1 차에서는 133 기관 중 1 기관에서만 음성으로 잘못 보고하 였고, 2 차에서는 135 기관 중 전 기관에서 양성으로 보고하여 각각 $99.6 \%, 100.0 \%$ 의 높은 일치율을 보였다(Table 8).

\section{4) C형간염항체}

Anti-HCV검사에 대한 신빙도조사 결과, 1 차의 $15-\mathrm{S}-3$ 와 2 차의 $15-\mathrm{S}-8$ 은 양성 검체로 각각 825 기관 중 821 기관, 814 기 관 중 812 기관이 양성으로 보고하여 각각 $99.5 \%, 99.8 \%$ 의 높 은 일치율을 보였다(Table 9). 한편 1차의 15-S-4와 2차의 15S-9은 음성 검체로 825 기관 중 823기관, 814 기관 중 811 기관 이 음성으로 보고하여 각각 $99.8 \%, 99.6 \%$ 의 높은 일치율을 보였다(Table 9). 

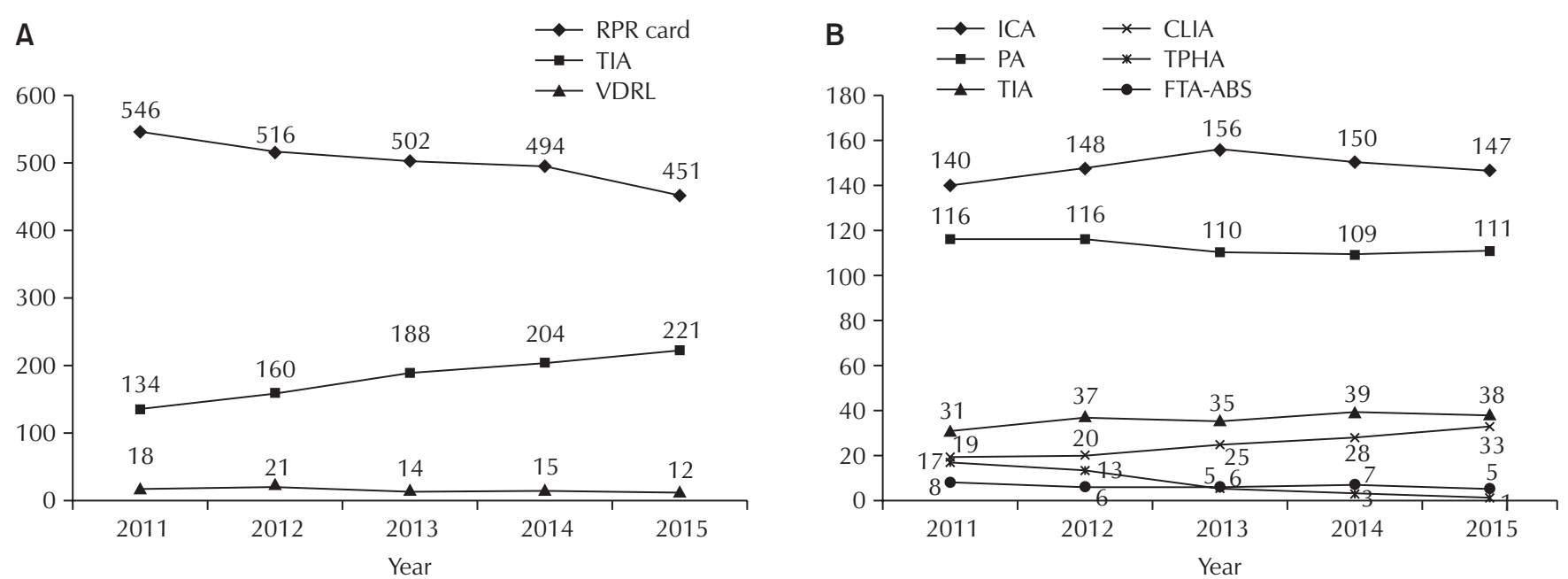

Fig. 2. Trend of methods used in STS. (A) For non-T, laboratories using TIA are steadily increasing, while RPR card tests are decreasing. (B) On the other hand, for T, there is little change in methods utilized, except a slightly increasing tendency in CLIA and TIA. The $\mathrm{X}$-axis shows the time-points tested, The $\mathrm{Y}$-axis shows the result values. The units of the $\mathrm{Y}$-axis are the signal to cutoff ratio (S/CO) in HBsAg, antibody to hepatitis $\mathrm{C}$ virus, antibody to human immnodeficiency virus; IU/L in antibody to HBsAg; treponemal unit (T.U.) in anti-TP. Abbreviations: STS, serologic tests for syphilis; T, treponemal; TIA, turbidoimmunoassay; RPR card, rapid plasma regain card; CLIA, chemiluminescence immunoassay; VDRL, Venereal Disease Research Laboratory test; ICA, immunochromatography assay; PA, particle agglutination; TPHA, Treponema pallidum hemagglutionation assay; FTA-ABS, fluorescent treponemal antibody absorption test; HBsAg, hepatitis B surface antigen.

Table 6. Results of HBsAg proficiency testing of 2015

\begin{tabular}{|c|c|c|c|c|c|c|c|c|c|c|c|c|c|c|c|c|c|c|c|c|}
\hline \multirow{3}{*}{ Method } & \multicolumn{10}{|c|}{ 1st trial } & \multicolumn{10}{|c|}{ 2nd trial } \\
\hline & \multicolumn{5}{|c|}{ HBsAg (15-S-3) } & \multicolumn{5}{|c|}{ HBsAg (15-S-4) } & \multicolumn{5}{|c|}{ HBsAg (15-S-8) } & \multicolumn{5}{|c|}{ HBsAg (15-S-9) } \\
\hline & $\mathrm{N}$ & WP & $\mathbf{P}$ & SP & Total & $\mathrm{N}$ & WP & $\mathbf{P}$ & SP & Total & $\mathrm{N}$ & WP & $P$ & SP & Total & $\mathrm{N}$ & WP & $\mathrm{P}$ & SP & Total \\
\hline EIA & - & - & 4 & 2 & 6 & 5 & 1 & - & - & 6 & - & - & 3 & 2 & 5 & 5 & - & - & - & 5 \\
\hline CLIA & - & - & 348 & 67 & 415 & 415 & - & - & - & 415 & - & - & 336 & 75 & 411 & 406 & 2 & 2 & 1 & 411 \\
\hline FEIA & - & - & 30 & 2 & 32 & 32 & - & - & - & 32 & - & - & 29 & 3 & 31 & 32 & - & - & - & 32 \\
\hline ECLIA & - & - & 277 & 51 & 328 & 326 & - & 2 & - & 328 & - & 1 & 263 & 51 & 315 & 314 & - & 1 & - & 315 \\
\hline ICA & 1 & - & 241 & 24 & 266 & 263 & 2 & 1 & - & 266 & - & - & 256 & 26 & 282 & 282 & - & - & - & 282 \\
\hline Total & 1 & - & 900 & 146 & 1,047 & 1,041 & 3 & 3 & - & 1,047 & - & 1 & 887 & 157 & 1,044 & 1,039 & 2 & 3 & 1 & 1,045 \\
\hline
\end{tabular}

Abbreviations: HBsAg, hepatitis B surface antigen; N, negative; WP, weakly positive; P, positive; SP, strongly positive; EIA, enzyme immunoassay; CLIA, chemiluminescence immunoassay; FEIA, fluorescent enzyme immunoassay; ECLIA, electro-chemiluminescence immunoassay; ICA, immunochromatography assay.

\section{5) 에이즈항체}

Anti-HIV검사에 대한 신빙도조사 결과, 1 차의 $15-\mathrm{S}-4$ 와 2 차의 $15-\mathrm{S}-9$ 는 양성 검체로 각각 819 기관 중 815 기관, 805 기 관 중 803 기관이 양성으로 보고하여 각각 $99.5 \%, 99.8 \%$ 의 높 은 일치율을 보였다(Table 10). 한편 1차의 $15-\mathrm{S}-3$ 와 2차의 $15-\mathrm{S}-8$ 은 음성 검체로 819 기관 중 815 기관, 805 기관 중 796 기 관이 음성으로 보고하여 각각 $99.5 \%, 98.9 \%$ 의 일치율을 보였 다(Table 10).

\section{6) 매독혈청검사}

STS검사에 대한 신빙도조사 결과, 1 차의 $15-\mathrm{S}-5$ 와 2차의 15-S-10은 모두 양성 검체로 비트레포네마검사에서는 681기 관 중 675 기관, 684 기관 중 680 기관이 약양성 이상으로 보고 하여 각각 $99.1 \%, 99.4 \%$ 의 높은 일치율을 보였고, 트레포네 마검사에서는 334 기관 중 전 기관, 335 기관 중 333 기관이 약 양성 이상으로 보고하여 각각 $100.0 \%, 99.4 \%$ 의 높은 일치율 을 보였다(Table 11). 
Table 7. Results of anti-HBs proficiency testing of 2015

\begin{tabular}{|c|c|c|c|c|c|c|c|c|c|c|c|c|c|c|c|c|c|c|c|c|}
\hline \multirow{3}{*}{ Method } & \multicolumn{10}{|c|}{ 1st trial } & \multicolumn{10}{|c|}{ 2nd trial } \\
\hline & \multicolumn{5}{|c|}{ Anti-HBs (15-S-3) } & \multicolumn{5}{|c|}{ Anti-HBs (15-S-4) } & \multicolumn{5}{|c|}{ Anti-HBs (15-S-8) } & \multicolumn{5}{|c|}{ Anti-HBs (15-S-9) } \\
\hline & $\mathrm{N}$ & WP & $\mathbf{P}$ & SP & Total & $\mathrm{N}$ & WP & $\mathrm{P}$ & SP & Total & $\mathrm{N}$ & WP & $\mathrm{P}$ & SP & Total & $\mathrm{N}$ & WP & $\mathbf{P}$ & SP & Total \\
\hline EIA & 6 & - & - & - & 6 & - & - & 4 & 2 & 6 & 5 & - & - & - & 5 & - & - & 3 & 2 & 5 \\
\hline CLIA & 407 & 2 & - & - & 409 & - & - & 302 & 107 & 409 & 399 & - & 7 & - & 406 & - & - & 366 & 40 & 406 \\
\hline FEIA & 32 & - & - & - & 32 & - & 1 & 26 & 5 & 32 & 31 & - & - & - & 31 & - & - & 26 & 5 & 31 \\
\hline ECLIA & 309 & - & 1 & - & 310 & - & - & 248 & 62 & 310 & 296 & 1 & - & - & 297 & - & 1 & 275 & 21 & 297 \\
\hline ICA & 263 & - & 1 & 1 & 265 & - & - & 249 & 16 & 265 & 282 & - & - & - & 282 & - & 1 & 276 & 5 & 282 \\
\hline Total & 1,017 & 2 & 2 & 1 & 1,022 & - & 1 & 829 & 192 & 1,022 & 1,013 & 1 & 7 & - & 1,021 & - & 2 & 946 & 73 & 1,021 \\
\hline
\end{tabular}

Abbreviations: Anti-HBs, antibody to hepatitis B surface antigen; N, negative; WP, weakly positive; P, positive; SP, strongly positive; EIA, enzyme immunoassay; CLIA, chemiluminescence immunoassay; FEIA, fluorescent enzyme immunoassay; ECLIA, electro-chemiluminescence immunoassay; ICA, immunochromatography assay.

Table 8. Results of anti-HBc proficiency testing of 2015

\begin{tabular}{|c|c|c|c|c|c|c|c|c|c|c|c|c|c|c|c|c|c|c|c|c|}
\hline \multirow{3}{*}{ Method } & \multicolumn{10}{|c|}{ 1st trial } & \multicolumn{10}{|c|}{ 2nd trial } \\
\hline & \multicolumn{5}{|c|}{ Anti-HBc (15-S-3) } & \multicolumn{5}{|c|}{ Anti-HBc (15-S-4) } & \multicolumn{5}{|c|}{ Anti-HBc (15-S-8) } & \multicolumn{5}{|c|}{ Anti-HBc (15-S-9) } \\
\hline & $\mathrm{N}$ & WP & $\mathbf{P}$ & SP & Total & $\mathrm{N}$ & WP & $\mathbf{P}$ & SP & Total & $\mathrm{N}$ & WP & $\mathbf{P}$ & SP & Total & $\mathbf{N}$ & WP & $\mathbf{P}$ & SP & Total \\
\hline MEIA & - & - & 1 & - & 1 & - & - & 1 & - & 1 & - & - & 1 & - & 1 & - & - & 1 & - & 1 \\
\hline CLIA & - & - & 88 & 2 & 90 & 1 & - & 87 & 2 & 90 & - & - & 87 & 3 & 90 & - & - & 89 & 1 & 90 \\
\hline FEIA & - & - & 4 & - & 4 & - & - & 4 & - & 4 & - & - & 5 & - & 5 & - & - & 5 & - & 5 \\
\hline ECLIA & - & - & 38 & - & 38 & - & - & 38 & - & 38 & - & - & 39 & - & 39 & - & - & 39 & - & 39 \\
\hline Total & - & - & 131 & 2 & 133 & 1 & - & 130 & 2 & 133 & - & - & 132 & 3 & 135 & - & - & 134 & 1 & 135 \\
\hline
\end{tabular}

Abbreviations: Anti-HBc, antibody to hepatitis core antigen; N, negative; WP, weakly positive; P, positive; SP, strongly positive; MEIA, microparticle enzyme immunoassay; CLIA, chemiluminescence immunoassay; FEIA, fluorescent enzyme immunoassay; ECLIA, electrochemiluminescence immunoassay.

Table 9. Results of anti-HCV proficiency testing of 2015

\begin{tabular}{|c|c|c|c|c|c|c|c|c|c|c|c|c|c|c|c|c|c|c|c|c|}
\hline \multirow{3}{*}{ Method } & \multicolumn{10}{|c|}{ 1st trial } & \multicolumn{10}{|c|}{ 2nd trial } \\
\hline & \multicolumn{5}{|c|}{ Anti-HCV (15-S-3) } & \multicolumn{5}{|c|}{ Anti-HCV (15-S-4) } & \multicolumn{5}{|c|}{ Anti-HCV (15-S-8) } & \multicolumn{5}{|c|}{ Anti-HCV (15-S-9) } \\
\hline & $\mathrm{N}$ & WP & $\mathbf{P}$ & SP & Total & $\mathbf{N}$ & WP & $\mathbf{P}$ & SP & Total & $\mathrm{N}$ & WP & $\mathbf{P}$ & SP & Total & $\mathrm{N}$ & WP & $\mathbf{P}$ & SP & Total \\
\hline EIA & - & - & 18 & - & 18 & 18 & - & - & - & 18 & - & - & 14 & - & 14 & 14 & - & - & - & 14 \\
\hline CLIA & - & - & 332 & 12 & 344 & 344 & - & - & - & 344 & - & 3 & 322 & 19 & 344 & 342 & - & 2 & - & 344 \\
\hline ECLIA & - & - & 188 & 3 & 191 & 190 & - & 1 & - & 191 & - & 4 & 175 & 3 & 182 & 182 & - & - & - & 182 \\
\hline ICA & 4 & 7 & 254 & 7 & 272 & 271 & - & 1 & - & 272 & 2 & 5 & 265 & 2 & 274 & 273 & - & 1 & - & 274 \\
\hline Total & 4 & 7 & 792 & 22 & 825 & 823 & - & 2 & - & 825 & 2 & 12 & 776 & 24 & 814 & 811 & - & 3 & - & 814 \\
\hline
\end{tabular}

Abbreviations: Anti-HCV, anti-hepatitis C virus; N, negative; WP, weakly positive; P, positive; SP, strongly positive; EIA, enzyme immunoassay; CLIA, chemiluminescence immunoassay; ECLIA, electro-chemiluminescence immunoassay; ICA, immunochromatography assay.

\section{고찰}

면역혈청분과위원회의 2015년 바이러스 항원/항체 및 매독 항체검사 신빙도조사사업은 5 월과 11 월에 실시되었는데, 각 각 1,071 기관과 1,074 기관에 검체를 발송하여 1,2 차에 참여
한 기관이 각각 1,055 기관(98.5\%), 1055 기관(98.2\%)으로 매 우 높은 참여율을 보였다. 2015년 참여기관은 총 1,074 기관으 로 2014년에 비하여 10 기관(0.9\%)이 증가하여 가입기관 증 가율이 다소 둔화되었다[7]. 신빙도조사에 사용되는 검체는 matrix effect를 배제하기 위해 '인체유래 고위험군바이러스 
Journal of LABORATORY MEDICINE and QUALITY ASSURANCE

Young Joo Cha et al • EQA Report for Immunoserology (2015)

Table 10. Results of anti-HIV proficiency testing of 2015

\begin{tabular}{|c|c|c|c|c|c|c|c|c|c|c|c|c|c|c|c|c|c|c|c|c|}
\hline \multirow{3}{*}{ Method } & \multicolumn{10}{|c|}{ 1st trial } & \multicolumn{10}{|c|}{ 2nd trial } \\
\hline & \multicolumn{5}{|c|}{ Anti-HIV (15-S-3) } & \multicolumn{5}{|c|}{ Anti-HIV (15-S-4) } & \multicolumn{5}{|c|}{ Anti-HIV (15-S-8) } & \multicolumn{5}{|c|}{ Anti-HIV (15-S-9) } \\
\hline & $\mathrm{N}$ & WP & $\mathrm{P}$ & SP & Total & $\mathrm{N}$ & WP & $\mathbf{P}$ & SP & Total & $\mathbf{N}$ & WP & $\mathrm{P}$ & SP & Total & $\mathrm{N}$ & WP & $\mathrm{P}$ & SP & Total \\
\hline EIA & 20 & - & - & - & 20 & - & - & 18 & 2 & 20 & 17 & - & 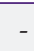 & - & 17 & - & - & 15 & 2 & 17 \\
\hline CLIA & 354 & 1 & 1 & - & 356 & 1 & - & 325 & 30 & 356 & 335 & 2 & 7 & - & 344 & - & - & 318 & 26 & 344 \\
\hline FEIA & 19 & - & - & - & 19 & - & - & 19 & - & 19 & 18 & - & - & - & 18 & - & - & 18 & - & 18 \\
\hline ECLIA & 215 & - & 1 & - & 216 & 1 & - & 197 & 18 & 216 & 204 & - & - & - & 204 & 1 & 1 & 190 & 12 & 204 \\
\hline ICA & 207 & - & 1 & - & 208 & 2 & 1 & 192 & 13 & 208 & 222 & - & - & - & 222 & 1 & 2 & 216 & 3 & 222 \\
\hline Total & 815 & 1 & 3 & - & 819 & 4 & 1 & 751 & 63 & 819 & 796 & 2 & 7 & - & 805 & 2 & 3 & 757 & 43 & 805 \\
\hline
\end{tabular}

Abbreviations: Anti-HIV, anti-human immunodeficiency virus; N, negative; WP, weakly positive; P, positive; SP, strongly positive; EIA, enzyme immunoassay; CLIA, chemiluminescence immunoassay; FEIA, fluorescent enzyme immunoassay; ECLIA, electro-chemiluminescence immunoassay; ICA, immunochromatography assay.

Table 11. Results of STS proficiency testing of 2015

\begin{tabular}{|c|c|c|c|c|c|c|c|c|c|}
\hline \multicolumn{2}{|c|}{ Method } & \multicolumn{4}{|c|}{ STS (15-S-5) } & \multicolumn{4}{|c|}{ STS (15-S-10) } \\
\hline 19tet & & \multirow{2}{*}{$\begin{array}{c}\text { NR } \\
5\end{array}$} & \multirow{2}{*}{$\frac{\text { WR }}{13}$} & \multirow{2}{*}{$\frac{\mathrm{R}}{430}$} & \multirow{2}{*}{$\begin{array}{r}\text { Total } \\
448\end{array}$} & \multirow{2}{*}{$\begin{array}{c}\text { NR } \\
4\end{array}$} & \multirow{2}{*}{$\begin{array}{c}\text { WR } \\
10\end{array}$} & \multirow{2}{*}{$\frac{\mathrm{R}}{437}$} & \multirow{2}{*}{$\begin{array}{r}\text { Total } \\
451\end{array}$} \\
\hline Non-treponemal & RPR card & & & & & & & & \\
\hline & VDRL & - & - & 15 & 15 & - & 2 & 10 & 12 \\
\hline & TIA & 1 & 2 & 215 & 218 & - & 3 & 218 & 221 \\
\hline & Subtotal & 6 & 15 & 660 & 681 & 4 & 15 & 665 & 684 \\
\hline \multirow[t]{7}{*}{ Treponemal } & TPHA & - & - & 3 & 3 & - & - & 1 & 1 \\
\hline & PA & - & - & 111 & 111 & 1 & - & 110 & 111 \\
\hline & FTA-ABS & - & - & 6 & 6 & - & - & 5 & 5 \\
\hline & ICA & - & - & 145 & 145 & 1 & - & 146 & 147 \\
\hline & CLIA & - & - & 32 & 32 & - & - & 33 & 33 \\
\hline & TIA & - & - & 37 & 37 & - & - & 38 & 38 \\
\hline & Subtotal & - & - & 334 & 334 & 2 & - & 333 & 335 \\
\hline Total & & 6 & 15 & 994 & 1,015 & 6 & 15 & 998 & 1,019 \\
\hline
\end{tabular}

Abbreviations: STS, serologic tests for syphilis; NR, non-reactive; WR, weakly reactive; R, reactive; RPR card, rapid plasma regain card; VDRL, Venereal Disease Research Laboratory test; TIA, turbidoimmunoassay; TPHA, Treponema pallidum hemagglutionation assay; PA, particle agglutination; FTA-ABS, fluorescent treponemal antibody absorption test; ICA, immunochromatography assay; CLIA, chemiluminescence immunoassay.

소재은행’인 ‘혈청검체은행’으로부터 검증 받은 혈청을 분양받 아 각 종목의 양성과 음성 신빙도조사 검체를 인간혈청으로 자 가제조하였고 병내 균질성, 병간 균질성 및 안정성을 검증하여 발송하였다.

바이러스 항원 및 항체검사에 대한 검사방법은 과거에 사용 하던 RPHA, PHA법 및 RIA법이 시약 단종과 더불어 CLIA 및 ECLIA 법으로 전환되어 65\%-69\%의 기관에서 사용되고 있고, 장비를 사용하지 않는 기관에서는 간이검사법인 ICA 법(27\%-34\%)을 사용하는 현상을 보였다. 2014년 신빙도 조사 결과, $\mathrm{HBsAg}$ 과 anti-HBs검사에서 양성 검체 일치율
은 99.9\%-100.0\%로 매우 우수하였는데, 음성 검체 일치율 은 99.2\%-99.5\%로 양성 검체 일치율보다 다소 낮았는데, 이 는 검사의 높은 민감도로 인하여 소수의 기관에서 위양성을 보 고한 때문으로 생각된다. Anti-HIV검사에서도 역시 양성 검 체 일치율(99.5\%-99.8\%)에 비하여 음성 검체 일치율 $(98.9 \%$ 99.5\%)이 다소 떨어졌는데, 이 역시 검사의 높은 민감도로 인 하여 소수의 기관에서 위양성을 보고한 때문으로 생각된다. 반 면 anti-HIV검사에서는 소수의 기관에서 양성 검체를 음성으 로 보고한 결과가 발견되어 보다 엄격한 질 관리가 필요하다 고 생각된다. Anti-HCV검사에서는 양성 검체 일치율 및 음성 
검체 일치율이 모두 $99.5 \%$ 이상으로 높은 일치율을 보였다. Anti-HCV검사의 경우 $34 \%$ 의 기관에서 ICA검사를 실시하고 있었는데, 민감도가 다소 낮은 ICA검사결과도 매우 우수한 일 치율을 보여 국내 ICA검사키트의 품질이 많이 향상되었다고 생각되지만, 아직까지도 양성 검체에서 음성을 보인 경우는 모 두 ICA검사를 사용하는 기관이므로 ICA검사를 사용하는 경 우 보다 세심한 정도관리가 필요하다고 생각된다.

$\mathrm{ICA}$ 검사의 경우 검사키트의 예민도와 함께 검사 시 판독시 간 및 기준, 시약의 변질이나 보관상태(습기 차단, 밀봉 여부) 등도 결과에 중요한 영향을 미치고, 제품에 따라 로트별로 결 과에 차이가 발생하는 경우도 관찰되므로 이와 같은 요인들이 검사결과에 영향을 줄 수 있다. 한편 ICA 시약의 경우 개봉 후 시간이 경과할수록 대조선이나 검량선의 색깔이 흐려지는 것 을 경험(자료 미제시)할 수 있었는데, 정확한 결과를 위하여서 는 시약 개봉 후 밀봉하여 습기를 차단하는 등의 보관상태가 매우 중요하다고 생각되고, 시약 개봉 후의 유효기간 등이 설 정되어야 할 것으로 생각된다.

STS검사 중 non-T검사는 RPR법을 사용하고 있는 기관이 451 기관(65.9\%)으로 아직까지 가장 많이 사용되고 있는 방법 이지만 서서히 감소하는 추세이고, TIA법의 경우 2011년 134 기관에서 서서히 증가하여 2015년에는 221기관(32.3\%)에서 사용하고 있었다(Fig. 2). 한편 T검사에서는 147기관(43.9\%) 에서 ICA법, 11 기관(33.1\%)에서 PA법을 사용하고 있었고, TIA 및 CLIA를 사용하고 있는 기관이 각각 38 기관(11.3\%), 33 기관 $(9.9 \%)$ 으로 아직 소수이기는 하지만 서서히 증가하고 있는 추세이다(Fig. 2). 따라서 STS검사의 경우 자동화가 가 능한 방향으로 검사방법이 전환되고 있는 추세라고 생각된다. 다만 최근 증가되고 있는 TIA법의 경우 주의할 점은 검체가 혈장인 경우 항응고제의 종류에 따라 특정 검체에서는 위음성, 위양성 반응을 보일 수 있다는 점을 숙지하고 사용하여야 할 것으로 생각된다.

신빙도조사의 결과 처리를 위하여 검사결과, 방법, 시약 및 기기를 코드화하여 결과를 보고하도록 하고 있는데, 이 표기가 정확하지 않아 분석에 많은 어려움이 있었다. 특히 바이러스 종목을 장비로 검사하는 기관은 장비에서 산출되는 수치를 적 어 보내야 하지만, 이는 정량값을 의미하는 것이 아니므로 결 과코드는 정성(음성 또는 양성)을 선택하여 주시고, 수치값도 함께 보내줘야 되는데, 이를 일일이 확인하여 수정하는 번거 로움이 있었다. 각 검사마다 결과표기방법을 표준화하여 평가 하여야 보다 정확한 신빙도조사가 될 수 있다고 생각되고, 참 여기관, 시약, 기기 및 방법 간의 비교가 가능하다고 생각된다. 특히 2005년부터 시작한 인터넷 결과입력이 2012년도 이후부
터 $100 \%$ 로 모든 참여기관이 손쉽게 인터넷 결과입력을 사용 하고 있다. 그러나 양성과 음성 결과코드를 반대로 입력하는 등 인터넷 입력과정에서 발생한 것으로 추정되는 오류가 상당 수 발견되어 가능한 확인 후 수정하여 통계 처리하였지만, 일 부 발견되지 않은 오류도 있을 것으로 생각되므로, 결과입력 시의 세심한 주의가 필요할 것으로 생각된다. 이러한 사무적 오차 역시 정도관리의 한 부분이므로 각 기관에서는 결과입력 시 주의해서 결과를 입력해야 할 것으로 생각된다.

\section{면역혈청분과위원회 위원(2015)}

차영주(위원장, 중앙대학교 의과대학), 배재훈(간사, 중앙 대학교병원), 권소영(대한적십자사), 김신규(한양대학교 의과 대학), 김재룡(계명대학교 의과대학), 김현숙(연세대학교 의 과대학), 박성훈(영남대병원), 박애자(중앙대학교 의과대학), 채석래(동국대학교 의과대학), 조윤정(고려대학교 의과대학), 박규은(국군의학연구소)

\section{REFERENCES}

1. Kang DY, Kim KH, Lee DH, Lee YW, Park CK. Report on serology survey in Korea 1982. J Lab Med Qual Assur 1983;5:39-44.

2. Cho HI, Kang DY, Kim SI, Kim KH, Lee YW, Choi SY, et al. Annual report on quality assessment in immunoserology and blood bank tests in Korea (1983). J Lab Med Qual Assur 1984;6:31-8.

3. Chi HS, Kang DY, Kim HS, Park MH, Shim JW, Lee DH, et al. Annual report on external quality assessment in immunoserology in Korea (1986). J Lab Med Qual Assur 1987;9:37-46.

4. Kim HS, Kim DW, Kim JS, Kim TY, Park MH, Park AJ, et al. Annual report on external quality assessment in immunoserology in Korea (1993). J Lab Med Qual Assur 1994;16:33-46.

5. Cha YJ, Kwon SY, Kum DG, Kim SW, Kim TY, Kim JR, et al. Annual report on external quality assessment in immunoserology in Korea (2004). J Lab Med Qual Assur 2005;27:37-57.

6. Lee JH, Cha YJ, Bae JH, Chae SL; Immunoserology Subcommittee, The Korean Association of Quality Assurance for Clinical Laboratory. Annual report on external qua- 


\section{Journal of LABORATORY MEDICINE and QUALITY ASSURANCE}

Young Joo Cha et al • EQA Report for Immunoserology (2015)

lity assessment of viral markers and serological tests for syphilis in Korea (2013). J Lab Med Qual Assur 2014;36: 161-70.

7. Cha YJ, Bae JH, Park Q, Chae SL; Immunoserology Subcommittee, The Korean Association of External Quality
Assessment Service. Annual report on the external quality assessment scheme of viral markers and serological tests for syphilis in Korea (2014). J Lab Med Qual Assur 2015; 37:124-33.

\section{바이러스 항원/항체 및 매독항체검사 신빙도조사 결과보고} (2015)

\section{차영주 ${ }^{1}$ - 배재훈 ${ }^{1}$ - 정영순 ${ }^{1}$ - 채석래 ${ }^{2}$ - 대한임상검사정도관리협회 면역혈청 분과위원회 \\ 중앙대학교 의과대학 진단검사의학교실, ${ }^{2}$ 동국대학교 의과대학 동국대학교일산병원 진단검사의학교실}

대한임상검사정도관리협회 면역혈청분과위원회의 2015년 바이러스 항원/항체 및 매독항체검사 (serologic test for syphilis, STS) 신빙도조사사업은 5월과 11월에 2회에 걸쳐 시행되었다. 회차 마다 3 개의 혼주혈청 검체를 각각 1,071 기관, 1,074 기관에 검체를 발송하였다. 신빙도조사용 검체 는 제조 당일부터 발송 3일 후까지 3종류 이상의 검사방법으로 균질성과 안정성에 대한 검증을 실시 하였다. 참여기관은 1회차에 1,055기관(98.5\%), 2회차 1,055기관(98.2\%)이었다. 바이러스 항원/ 항체 및 STS 중 hepatitis B surface antigen에 가장 많은 기관이 참여하였고, hepatitis B surface antigen, anti-human immunodeficiency virus, anti-hepatitis C virus, STS, 및 anti-hepatitis $\mathrm{B}$ core anti-HBc 순으로 참여하였다. 바이러스 항원/항체검사 신빙도조사 결과 가장 많이 사용되고 있는 전기화학발광면역검사법을 포함한 화학발광면역검사법에서는 약간의 위양성 결과가 발생하였 고, 근래 사용이 증가하고 있는 면역크로마토그래피법은 그 품질이 매우 향상되었지만 여전히 위음성 결과에 주의하여야 할 것으로 생각된다. 한편 최근 STS에서는 혈구응집법 대신 면역크로마토그래피 법, 입자응집법, 혼탁면역검사법의 사용이 점차 증가하고 있다.

(J Lab Med Qual Assur 2016;38:214-224)

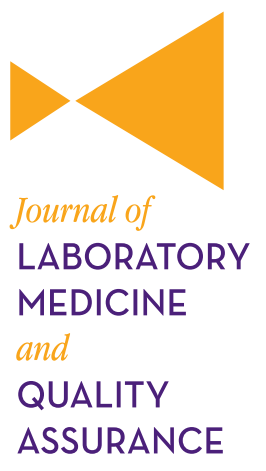

ASSURANCE 